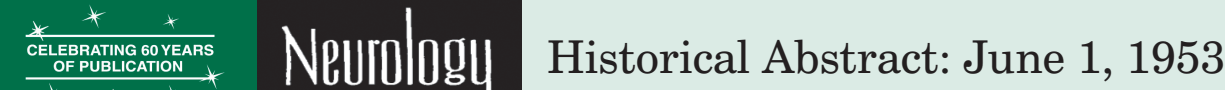 \\ * * *
}

\section{NEUROLOGIC SYMPTOMS AND SIGNS IN 347 CASES OF VERIFIED BRAIN TUMOR}

David G. Freeman, Manousos A. Petrohelos, and John W. Henderson

Neurology 1953;3:437-452

In making the diagnosis of a brain tumor, the only sure method is by surgical exploration and microscopic analysis. However, in order to make a tentative diagnosis of a space taking intracranial lesion there must be a strong suspicion initiated by the patient's symptoms and confirmed by a careful neurologic examination. In analyzing the records of 347 brain tumors seen over a ten year period at the University Hospital, Ann Arbor, a purely statistical summary has been made of the symptoms and signs which occurred with sufficient frequency to be significant in the diagnosis. The purpose of this paper is to tabulate these findings according to proven anatomic location of the tumor.

Free Access to this article at www.neurology.org/content/3/6/437

Comment from Robert A. Gross, MD, PhD, FAAN, Editor-in-Chief: One of the earliest contributions to this journal in oncology, a useful clinical compendium. 


\section{Neurology}

\section{Neurologic symptoms and signs in 347 cases of verified brain tumor}

David G. Freeman, Manousos A. Petrohelos and John W. Henderson

Neurology 2011;77;1286

DOI 10.1212/01.wnl.0000406396.50259.c5

This information is current as of September 26, 2011

\section{Updated Information \&}

Services

Permissions \& Licensing

Reprints including high resolution figures, can be found at:

http://n.neurology.org/content/77/13/1286.citation.full

Information about reproducing this article in parts (figures,tables) or in its entirety can be found online at:

http://www.neurology.org/about/about_the_journal\#permissions

Information about ordering reprints can be found online:

http://n.neurology.org/subscribers/advertise

Neurology ${ }^{\circledR}$ is the official journal of the American Academy of Neurology. Published continuously since 1951, it is now a weekly with 48 issues per year. Copyright Copyright $@ 2011$ by AAN Enterprises, Inc.. All rights reserved. Print ISSN: 0028-3878. Online ISSN: 1526-632X.

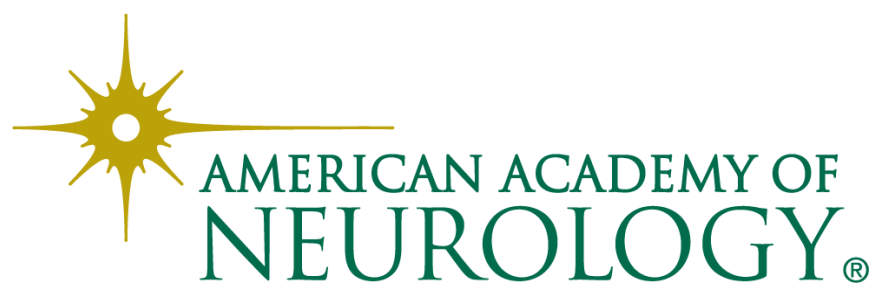

